doi $10.15826 /$ recon.2021.7.3.013

UDC 332.14

JEL R1, R5, O4

\title{
Socio-economic consequences of the first and second waves of the pandemic in Russian regions
}

\author{
A.A. Pobedin ${ }^{1} \bowtie$, N.R. Balynskaya ${ }^{2}$, D. Williams ${ }^{3}$ \\ ${ }^{1}$ Ural Institute of Management, Branch of RANEPA, Yekaterinburg, Russia; pobedin-aa@ranepa.ru \\ ${ }^{2}$ Nosov Magnitogorsk State Technical University, Magnitogorsk, Russia \\ ${ }^{3}$ Open University, Milton Keynes, United Kingdom
}

\begin{abstract}
Relevance. The spread of the coronavirus infection and the ensuing economic restrictions significantly influenced the main parameters of the socio-economic development of Russia and its territories, affecting the growth rate, production structure, territorial differentiation and competitiveness of Russian regions. Purpose of the study. The key goal of the study was to identify the socio-economic changes in the development of the country and its regions during the pandemic. Data and Methods. The analysis relies on open data on the socio-economic development of Russian regions for 2019-2021 (monthly, quarterly and annual periods), posted on the official website of Rosstat. Methodologically, the study is based on the comparative analysis of the data for the federal districts and their regions. Results. The study describes the main trends in the development of industry, trade, paid services, and investment potential and in the dynamics of unemployment and income in federal districts and regions. The first wave hit Russian regions the hardest due to the rigorous restrictions. Although no sharp recession was detected during the second wave, the stagnation in the key sectors persisted. The third wave is expected to have the same impact as the second.

Conclusions. After the second wave subsided, there was a revival of economic activity in the spring of 2021. However, this has not turned into a steady trend yet. The coronavirus pandemic affected the competitiveness of regions. The importance of certain factors (including those related to resource potential) decreased during the pandemic, while the role of the competitive position of regions in the distribution of federal budget transfers increased.
\end{abstract}

\section{KEYWORDS}

regions, federal districts of Russia, pandemic, coronavirus crisis, territorial differentiation, socio-economic development, regional development, dynamics of industrial production, investments of real incomes of the population, paid services to the population, regional policy

\section{FOR CITATION}

Pobedin, A.A., Balynskaya, N.R., \& Williams, D. (2021). Socioeconomic consequences of the first and second waves of the pandemic in Russian regions. R-economy, 7(3), 146-157. doi: $10.15826 /$ recon.2021.7.3.013

\section{Социально-экономические последствия первых двух волн пандемии для российских регионов}

\author{
А.А. Победин ${ }^{1} \bowtie$, Н.Р. Балынская ${ }^{2}$, Д. Уильямс ${ }^{3}$ \\ ${ }^{1}$ Уральский институт управления - филиал РАНХиГС при Президенте РФ, Екатеринбург, Россия; \\ pobedin-aa@ranepa.ru \\ ${ }^{2}$ Магнитогорский государственный технический университет им. Г.И. Носова, Магнитогорск, Россия \\ ${ }^{3}$ Открытый университет, Милтон-Кинс, Великобритания
}

\section{АННОТАЦИЯ}

Актуальность. Распространение коронавирусной инфекции и последовавшие экономические ограничения существенно повлияли на основные параметры социально-экономичного развития как России в целом, так и отдельных территорий, затронув темпы роста, структуру производства, территориальную дифференциацию и конкурентоспособность регионов России.

Цель исследования. Ключевой целью проведенного исследования являлось выявление особенностей деформации социально-экономического развития страны и регионов в условиях пандемии.

Данные и методы. Для анализа использованы открытые данные по социально-экономическому развития регионов России за 2019-2021 годы (помесячные, квартальные и годовые периоды), размещенные на официальном сайте Росстата. Автором проведено кросс-территориальное сравнение по федеральным округам Российской Федерации.

Результаты. Выявлены основные тенденции развития промышленности, торговли, платных услуг, инвестиционного потенциала, охарактеризована (C) Pobedin A.A., Balynskaya N.R., 2021

\section{КЛЮЧЕВЫЕ СЛОВА}

регионы, федеральные округа России, пандемия, коронавирусный кризис, территориальная дифференциация, социальноэкономическое развитие, региональное развитие, динамика промышленного производства, инвестиций реальных доходов населения, платных услуг населению, региональная политика 
динамика уровня безработицы и доходов населения в разрезе федеральных округов и регионов Российской Федерации. Наиболее болезненным для экономического и социального развития оказалось влияние первой волны пандемии, когда действовали максимальные ограничения для субъектов экономики. Вторая волна, не вызвав резкого спада, закрепила стагнацию в ключевых секторах экономики, третья волна, как ожидается, будет иметь схожее воздействие.

Выводы. Оживление экономической активности весной 2021 года, на спаде второй волны, пока не приобрело характер устойчивой тенденции. Пандемия коронавируса повлияла на конкурентоспособность регионов, значимость отдельных факторов конкурентоспособности (в том числе связанных с ресурсным потенциалом) во время пандемии снизилась, одновременно усилилась роль конкурентной позиции регионов при распределении трансфертов федерального бюджета.

\section{ДЛЯ ЦИТИРОВАНИЯ}

Pobedin, A.A., Balynskaya, N.R. \& Williams, D. (2021). Socioeconomic consequences of the first and second waves of the pandemic in Russian regions. R-economy, 7(3), 146-157. doi: $10.15826 /$ recon.2021.7.3.013

\section{Introduction}

The COVID-19 pandemic has significantly affected the socio-economic development of both Russia as a whole and its individual territories. The impact was produced by the restrictions aimed at reducing the incidence (these measures were primarily mobility restrictions), which caused a drop in domestic demand for the products of several industries, and as a result, a decrease in the incomes of people and enterprises. Since the problem is global in nature, external factors have been added to internal factors - a decrease in demand for Russian export products combined with a decrease in the world prices for Russian exports, the instability of the Russian currency exchange rate, which increased currency risks. To all this it is worth adding the problems of sluggish income growth and sluggish economic growth in recent years.

The development trends of the country as a whole shown by the analysis of macroeconomic data do not always reflect the processes at lower territorial levels, that is, the levels of federal districts and subjects of the Russian Federation. However, without understanding the territorial characteristics, the regulation of socio-economic development, especially during crises, such as the impact of the pandemic, cannot be effective, especially for countries with a large territory and high territorial differentiation such as Russia.

The main goal of this study was to identify the impact of the pandemic on the socio-economic development of the country and its regions. To achieve this goal, the following research tasks were set:

- identify and characterize the main areas of the pandemic's impact on the socio-economic development of Russia;
- select the key indicators of the pandemic's impact on regional development;

- to describe the key trends in the socio-economic development of the federal districts of Russia during the first and second waves of the pandemic.

\section{Theoretical framework}

The pandemic and its socio-economic consequences have become the focus of attention for many studies revealing various aspects of the problems faced on the national and regional levels.

The problem of organizing regional public administration during the pandemic is considered by Vladislavleva and Kerov (2020), who demonstrate the need to strengthen economic cooperation between Russian regions in emergencies, such as the coronavirus pandemic as well as in the conditions of radical changes and risks. In addition to federal authorities and state organizations, interregional coordination agencies should play an important role in the implementation of regional policies. The previous experience of interregional associations shows that the coronavirus problem can only be solved through mechanisms of interregional cooperation. After the pandemic, to restore the regional economy, the authors recommend to specify measures in the national plan related to the search for highly effective interregional economic ties. The study emphasizes the need to reboot the state policy in the field of regional development management.

Chisadza et al. (2021) discuss the effectiveness of public administration during the pandemic and assess the efficiency of the tools for limiting the spread of the disease in different countries and regions. It was found that the correlation between the severity of anti-COVID measures and the decrease in the incidence rate is not al- 
ways visible, however, as far as the economic consequences are concerned, such a relationship can be traced quite well. Therefore, the toolkit used in various countries is based on balancing between the restrictions and possible negative consequences for the economy.

Gordeev (2020) discusses the social aspect of the pandemic in the context of regional development. The situation of the crisis caused by the pandemic is becoming decisive for regulating the prospects for socio-economic development. This study examines the social aspects of the pandemic in the context of social heterogeneity in Russian regions. The study analyzes the dynamics of the pandemic in the regions, the specifics and effectiveness of social restrictions that transform the social space.

Tarasova and Tarasov (2020) deal with the labour relations during the pandemic, in particular the effects of restrictive measures on the labour market, both in the short and mid-term. In particular, they predicted the unemployment rate for 2021 at the level of $20 \%$. The authors pay special attention to the crisis processes in Rostov region, although the trends they describe are typical of many other Russian territories.

The socio-spatial effects of the pandemic are investigated by Kuebart and Stabler (2020) using the example of Germany. This study analyzes the key routes of movement of the population around the country, as well as the points of mass gathering of people, contributing to the incidence.

Kuchler et al. (2020) in their study pursue similar goals but study the possible directions of the spread of the coronavirus through the analysis of social connections in social networks.

Sleptsov and Potravnaya (2020) focus on the social changes in the northern regions of Russia in connection with the pandemic.

Morita et al. (2020) analyze the social activity of urban residents and conduct a comparative assessment of changing behaviour patterns of urban residents due to quarantine restrictions.

The financial and budgetary consequences of the coronavirus are discussed by Stepanova (2020), who analyzes the reasons for the increase in the deficit of regional budgets in Russia in 2020, the dynamics of income and expenditures, budget constraints caused by global problems, focusing on the aspect of the budget crisis in the context of the pandemic. She forecasts the development of the situation regarding regional budgets, discusses scenarios for further development of events.
Similar problems are considered by Ermakova (2020), who also assesses the budgetary effects associated with the implementation of the package of anti-crisis measures, including those aimed at supporting small and medium-sized businesses.

Milchakov (2021) discusses the priorities for regional development in the context of the pandemic and quarantine restrictions. His analysis focuses on the program for socio-economic development of struggling regions and cities with a population of one million during the pandemic. As a result, proposals for improving certain areas of the Spatial Development Strategy are formulated.

Banai (2020) focuses on the areas of urban development, changes in the components of the urban environment in the context of the pandemic, noting that even though pandemics reveal vulnerabilities in the development of urban systems, they can be a driving force for positive trends in planning sustainable urban environment in the future.

A fairly large array of works is aimed at studying the impact of the pandemic on the structure of regional economies and their separate elements. Andrea et al. (2021) investigate the impact of the pandemic on the structure of the regional economy using the example of Italian provinces. The authors note that the territorial concentration of economic activity in certain areas of the country acts as a means of transmission, thus creating a core-periphery model in the geography of COVID-19, which can follow the key directions of interregional economic ties.

Abramova (2021) studies the impact of the pandemic on the development of small and medium-sized businesses. Tsukhlo (2021) analyzes how the spread of the coronavirus affected industrial development. Martinez-Azua et al. (2021) discuss the activities of agricultural producers. Turgel et al. (2020) focus on the differentiation of agrarian regions. Coke-Hamilton examines the impact of the pandemic on the development of the tourism sector, which was one of the industries that was hit the hardest ${ }^{1}$. Gössling et al. (2020) consider the impact on tourism of the current pandemic on a local and global scale. Investment processes are studied by Rodionov at al. (2021). A separate group of studies consider the transformation of spatial structures under the influence of the pandemic (Adler et al., 2020; Matheson

${ }^{1}$ Coke-Hamilton, P. (2020). Impact of COVID-19 on tourism in small island developing states. UNCTAD. Retrieved from: https://unctad.org/en/pages/newsdetails.aspx?OriginalVersionID $=2341$ 
et al., 2020). Ivanov and Dolgui (2020) investigate changes in interregional trade influenced by the pandemic.

In addition to focusing on certain aspects of the impact of the pandemic, attempts are being made to gain a more in-depth understanding of its impact on regional development (Bailey et al., 2020; Zotikov, 2020; Kulova, 2020). The study by Zubarevich $(2020,2021)$ is of special interest in this respect. She analyzes the impact of the pandemic on the development of industry, trade, services and other elements of the regional socio-economic system. The paper makes interregional comparisons and discusses the reasons for the diverse impact of coronavirus restrictions on different territories.

This study seeks to continue the line of research based on the systemic comparison of the parameters of regional socio-economic development in the context of the pandemic. The emphasis is made on differentiating the consequences of the current crisis for different federal districts and thus provide a more comprehensive view of the entire territory of the country.

\section{Data and methods}

The research methodology is based on comparative cross-territorial analysis; traditional statistical methods, including time series analysis, indexes, grouping as well as graphical methods.

The information base of the study consists of indicators of regional socio-economic development published on the official website of the Federal State Statistics Service (Rosstat) ${ }^{2}$.

The following indicators were selected for the analysis: industrial production index, retail trade turnover, the volume of paid services to the population, the volume of investment in fixed assets, the unemployment rate according to the methodology of the International Labor Organization (ILO), the real income of the population, the cost of the fixed set of consumer goods and services for interregional comparisons of the purchasing power of the population. When constructing the time series, the data were used for 2019, 2020 and 2021 (depending on the indicators - from January to May or the first quarter).

The research comprised the following steps. At the first stage, the main development trends were identified during the first and second waves of the pandemic at the national level. For the periodization of coronavirus waves, the official

${ }^{2}$ https://rosstat.gov.ru/ data on the incidence of COVID-19 posted on the Stopcoronavirus resource ${ }^{3}$ were used. For the analysis of the national dynamics, the following areas of interest were chosen - industrial production, retail trade, the service sector and the labour market. At the second stage, the analysis of socio-economic dynamics at the level of federal districts and constituent entities was carried out. The federal districts were selected as the main level of analysis, the statistics on the smaller units were considered in the form of additional examples to explain the situation in a certain district. For each of the selected indicators, a comparison was made between the pre-crisis state, changes in the situation in 2020 and dynamics in January-May (or the first quarter) of 2021. At the third stage, the assessment of inter-territorial differences was carried out, highlighting the most significant features for individual federal districts and subjects of the Russian Federation. Territories sharing similar trends were united into groups. Upon completion of the third stage of the study, the main conclusions were drawn on the problems and dynamics of the country's development in the territorial context.

For calculations, construction of graphs and diagrams, Excel software package was used.

For federal districts, the following abbreviations are used: CFD - Central Federal District, NWFD - North-Western Federal District, SFD - Southern Federal District, NCFD - North Caucasian Federal District, VFD - Volga Federal District, UFD - Ural Federal District, SFD - Siberian Federal District, FEFD - Far Eastern Federal District.

\section{Results}

There were several waves in the pandemic, followed by measures on different levels and responses of the economic system as a whole. The first wave - from April to August 2020 - had a peak phase in mid-May, when the number of new cases was over 11.5 thousand per day; the second wave - from September 2020 to May 2021 - with a peak at the end of December, when the number of new cases amounted to over 29.9 thousand a day, and, finally, the third wave since June 2021, with a peak in mid-July, when the number of new cases was over 25.7 thousand a day. The first wave turned out to be the hardest for the socio-econo-

${ }^{3}$ Stopcoronavirus resource. Available at: https://stopcoronavirus.rf/info/ofdoc/reports/ 
mic system of the country since it was then that the quarantine restrictions were maximum (Fig. 1).

In April-May 2020, there was a sharp change in socio-economic indicators, primarily affecting the types of activities related to the services sectors (trade, public catering, transport and several others), primarily affected by quarantine restrictions. The volume of paid services reached its minimum in May, at the peak of the first wave, then, with the weakening of restrictive measures, the volume of paid services grew until September, without reaching the levels of the beginning of the year, stagnation was observed until January 2021, and only from February, there was a positive trend. The situation concerning retail developed very similarly - with minimum values in April 2020, growth resumed already from May, continuing through July inclusive, then there was stagnation until March 2021, and from April 2021 the growth resumed. The development of industry was more inert - on the one hand, the decline in production was not so sharp in the first wave - by May, the industrial production index reached $92 \%$ compared to the same month in 2019 (at that time, the indicators for paid services and retail trade were much worse $-62.4 \%$ and $82.5 \%$, respectively), after that there was stagnation until February 2021, and from March there was resumption of growth, but at a very moderate pace (in May, the industrial production index was $111.8 \%$ by May 2020 ). There was an increase in unemployment, which reached its maximum by August 2020 (6.4\%); later, the unemployment rate decreased, and by May 2021 it amounted to $4.9 \%$. Thus, the second wave of the pandemic, even though the incidence rate showed peak values (almost three times higher than during the first wave), for the economic system turned out to be not as catastrophic as the first, which, of course, is due to less severe restrictive measures. During the second wave, at the national level, economic stagnation was observed, without sharp jumps. The second wave ended with a noticeable revival in the economy, which, unfortunately, has not yet acquired a stable character.

The above-described tendencies observed at the macro-level acquire additional features on the regional level. Industrial growth in the pre-crisis year of 2019 was observed in all federal districts (Fig. 2), and in three districts the growth rates were higher than the average for Russia - in the Central (107.4), Far Eastern (106.6) and Ural (106.4) federal district. In the North Caucasian, Volga and Siberian districts, industrial growth rates were lower than the national ones, while remaining positive. In 2020, the industrial production index for the Russian Federation as a whole, after the two waves of the pandemic, amounted to $97.4 \%$. However, there were two federal districts the Central and North Caucasus districts - which showed industrial growth. Manufacturing indus-

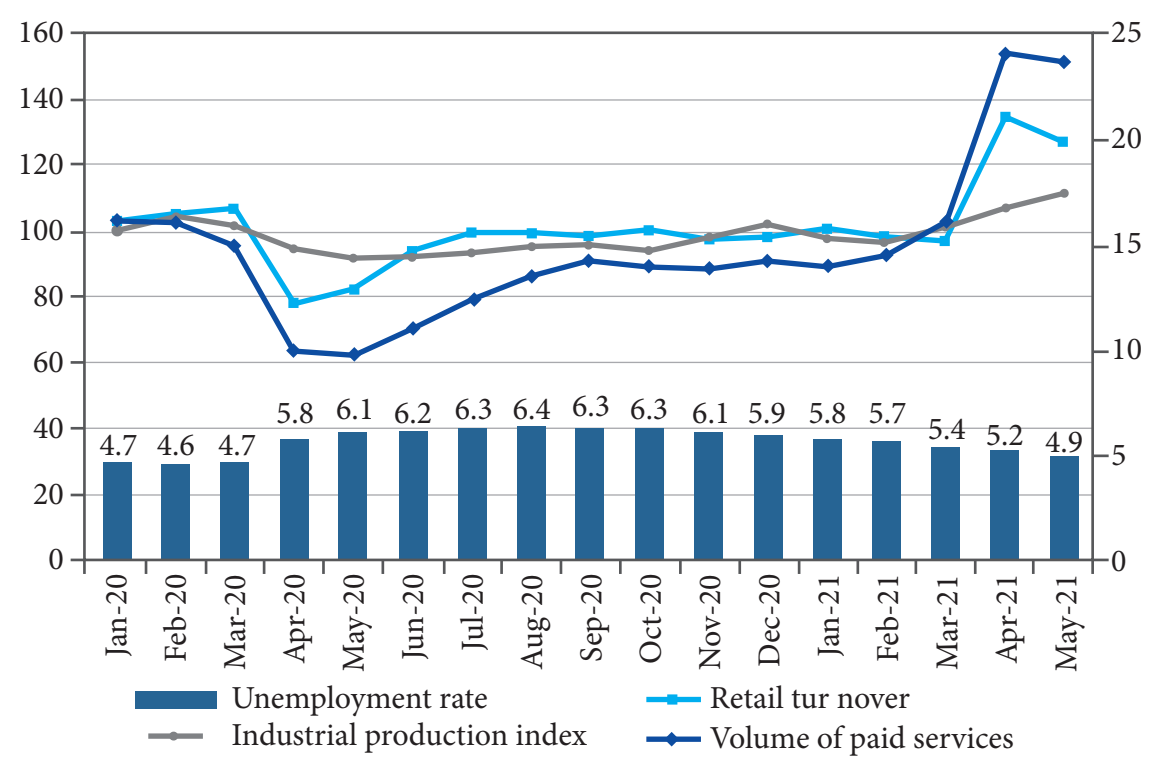

Figure 1. Dynamics of the industrial production index, retail trade turnover, the volume of paid services to the population (in \% of the same month of the previous year) and the unemployment rate according to the ILO methodology (in\%) from January 2020 to May 2021 in Russia

Source: the authors' calculations were based on the official data from Rosstat.

Retrieved from: https://rosstat.gov.ru/folder/10705 (Accessed data: 10.07.2021) 
tries were less affected by the pandemic and were able, after the first wave, to significantly restore their production volumes - in the manufacturing industry, which partly explains the rapid recovery of the industry in the Central, North-Western, South and North Caucasian districts. In the Urals, Siberian and Far Eastern districts, industrial recovery was slower due to the high share of the extractive industry in the structure of the economy. The Volga and Siberian districts, with a similar ratio of processing and extractive industries, showed different dynamics - in the Volga district by May 2021, industrial production increased, in comparison with May of the previous year, by $5.1 \%$, which is higher than the national level. The Siberian District was unable to restore its production levels. The most problematic part of the Siberian Federal District was the Krasnoyarsk Territory, where the May volume of industrial production is still $10 \%$ lower than the previous year's figure.

At the national level, there was an investment decline in 2020 ( $98.6 \%$ by 2019). However, during the first quarter of 2021, it was possible to achieve investment growth comparable to the rate of 2019 $(102 \%)$. But the investment dynamics at the level of individual federal districts was not linear (Fig. 3). First of all, different federal districts performed differently in the pre-crisis year of 2019 the highest rates of investment were observed in the Central Federal District (115\%), more modest, but exceeding the national average rates of investment growth were observed in the Far East, North

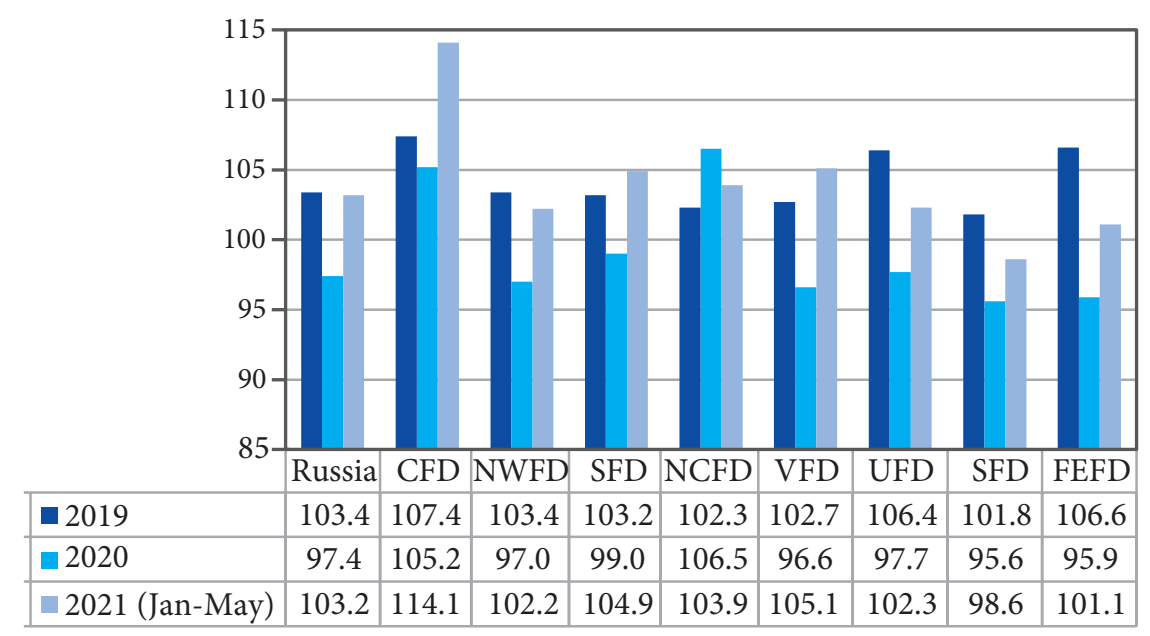

Figure 2. Index of industrial production on the national level and on the level of federal districts (in\% to the corresponding period of the previous year)

Source: the authors' calculations were based on the official data from Rosstat. Retrieved from: https://rosstat.gov.ru/folder/10705 (Accessed data: 10.07.2021)

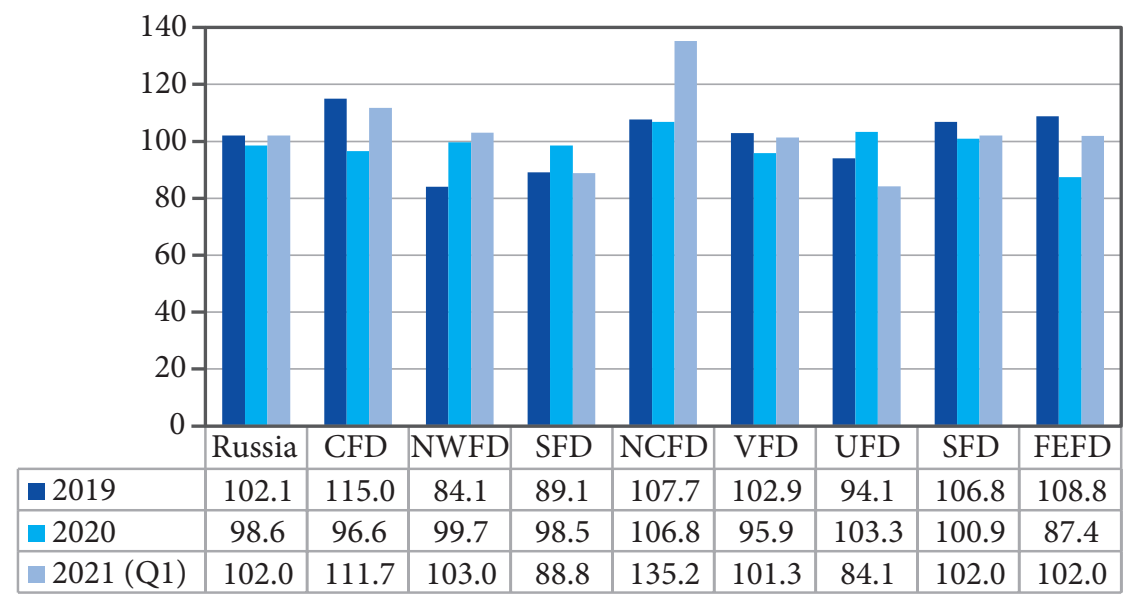

Figure 3. Dynamics of investment in fixed assets on the national level and on the level offederal districts (in comparable prices in\% to the corresponding period of the previous year)

Source: the authors' calculations were based on the official data from Rosstat.

Retrieved from: https://rosstat.gov.ru/folder/10705 (Accessed data: 10.07.2021) 
Caucasus and Siberian Districts. The Volga Federal District showed investment dynamics close to the data for the Russian Federation, and in the remaining three federal districts (NWFD, Southern Federal District and Ural Federal District), investment growth rates were not only lower than the national value but also showed negative dynamics, the lowest level was in the North-Western District, where there was a decrease in the volume of investment by $15.9 \%$, that is, even before the onset of the consequences of the pandemic, significant problems related to investment were observed in the economy, with significant differentiation between the territories of the country (at the level of individual regions, the differences are even more significant). During the crisis year of 2020, a slowdown in investment processes was observed in 6 out of 8 federal districts, while the North Caucasian Federal District and the Siberian Federal District were able to maintain positive values of investment growth, on the contrary, the sharpest decrease in the volume of investment was characteristic of the Central Federal District, where the decline was by $18.4 \%$. The lowest value of the indicator was observed in the Far Eastern Federal District, where the volume of investment was only $87.4 \%$ of the value of the pre-crisis year. Surprisingly, for the North-Western Federal District and the Ural Federal District, the situation has improved, and in the Ural District, the volume of investment in fixed assets even increased by $3.3 \%$. With the end of the second wave, according to the results of the 1st quarter of 2021, in some federal districts, as well as on the national level, the growth in the volume of investment resumed - this picture is typical of the Central, North Caucasian, Volga, Siberian and Far Eastern districts. In the North-Western District, investment indicators continued to improve, investment growth in the 1st quarter of 2021 was $3 \%$. However, in the Southern and Ural Federal Districts, a decrease in the volume of investment was observed, despite the positive dynamics in 2020, and in the Ural Federal District, the volume of investment in the first quarter of 2021 amounted to only $84.1 \%$ of the same period in 2020 , which is the lowest value. among the federal districts. Record-high investment growth was observed in the North Caucasian Federal District - 135.2\%. Thus, during the pandemic, the differentiation between the country's territories in terms of investment attractiveness only increased, while leaders and outsiders changed very quickly, which indicates the instability of investment processes in the current environment.

In contrast to the dynamics of investment, in the development of retail trade, the dynamics in most territories are similar and correspond to the changes observed on the national level (Fig. 4). All federal districts ended the pre-crisis year 2019 with a positive increase in retail trade turnover (from 1 to $3.3 \%$, depending on the territory). A similar situation was observed in the context of the constituent entities - the only exceptions were Arkhangelsk Region and the Nenets Autonomous Okrug, where there was a slight decrease, which, however, did not exceed $0.5 \%$. In 2020, almost all federal districts, as well as on the national level (as noted above), faced a decrease in retail turnover, except the North-Western Federal District, which managed to restore its retail turnover to the level of 2019. At the level of individual regions, a similar result was achieved only in 13 regions (4 of which are part of the North-Western Federal District): in Moscow, Ryazan, Vologda, Leningrad, Pskov, Saratov, Chelyabinsk regions, in Tyumen region (if we exclude the indicators of the Khanty-Mansi Autonomous Okrug and Yamalo-Nenets Autonomous Okrug), in the republics of Karelia, Adygea, Chechnya, Khabarovsk Territory and Chukotka Autonomous Okrug. As the second wave was over, the retail trade turnover in all federal districts increased, demonstrating the highest growth in the Central, North-Western, Southern and North-Caucasian districts. In projection to the level of the constituent entities of the Russian Federation, this trend was observed in most territories, except the Nenets Autonomous Okrug, Murmansk, Samara, Sverdlovsk, Omsk and Tomsk regions.

The dynamics of the volume of paid services is largely shaped by the trends similar to retail trade, albeit with some peculiarities. First of all, 3 out of 8 federal districts finished the pre-crisis year 2019 with a decline in this indicator - the Southern Federal District, the North Caucasian Federal District and the Far Eastern Federal District (Fig. 5). On the regional level, the volume of paid services in 2019 decreased in 34 regions, which were struggling even before the onset of the pandemic. During 2020, in all federal districts, there was a sharp decrease in the volume of paid services, which corresponds to the general federal dynamics (Fig. 1), and in the Central, North-Western, Ural and Far Eastern districts, the decline exceeded the national level. A similar 
picture was observed on the regional level. From January to May 2021, the volume of paid services, compared to the same period of the previous year, increased in all federal districts. The Southern, North Caucasian and Ural federal districts exceeded the national level. The Southern Federal District reached the record high of $121.6 \%$; the North Caucasus Federal District, 122.4\%. This growth is easy to explain for the Southern Federal District which saw a high demand for resort services due to the restrictions on outbound tourism.

As already noted, the pandemic was accompanied by an increase in the unemployment rate (Fig. 6) at the level of federal districts. This cor- responded to the national dynamics illustrated by Fig. 6: in 2020, unemployment increased in all federal districts, but in January-May 2021 the unemployment rate declined in almost all districts, except the Far East, where the number of unemployed continued to grow, and the unemployment rate reached $7 \%$. On the regional level, in 2020 unemployment increased in all regions; by May 2021 in most territories the unemployment rate decreased (although it still exceeded the level of 2019). In some regions, the unemployment continued to grow in 2021: Lipetsk, Astrakhan, Tomsk regions, the republics of Ingushetia, Tyva, Yakutia, Buryatia, the Jewish Autonomous Region and in

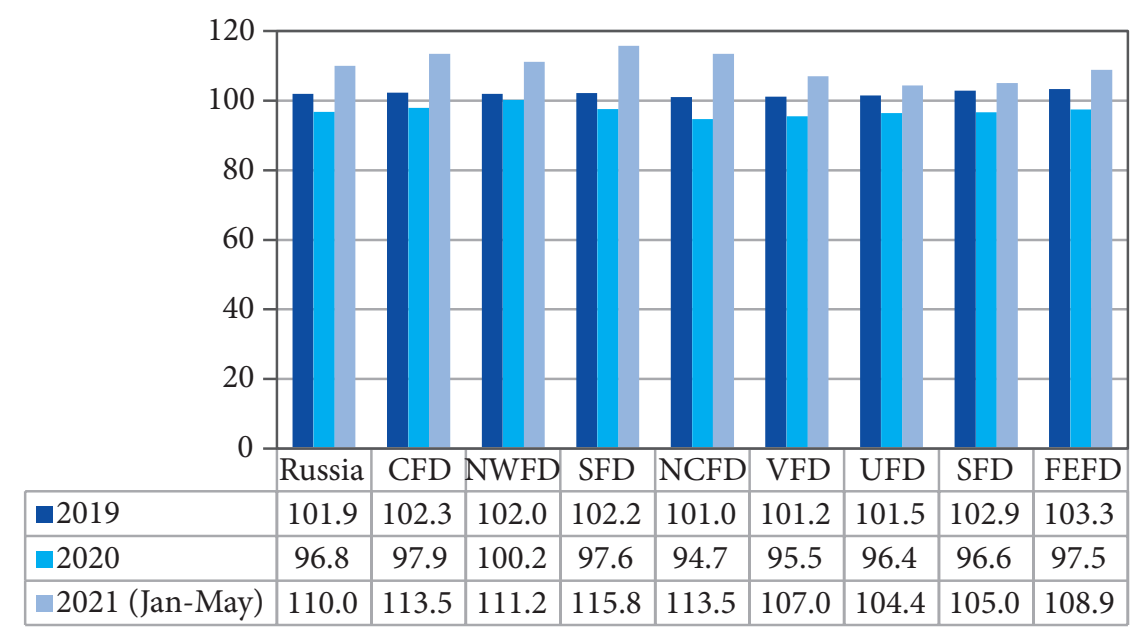

Figure 4. Dynamics of retail trade turnover on the national level and on the level of federal districts (in comparable prices in $\%$ to the corresponding period of the previous year)

Source: the authors' calculations were based on the official data from Rosstat.

Retrieved from: https://rosstat.gov.ru/folder/10705 (Accessed data: 10.07.2021)

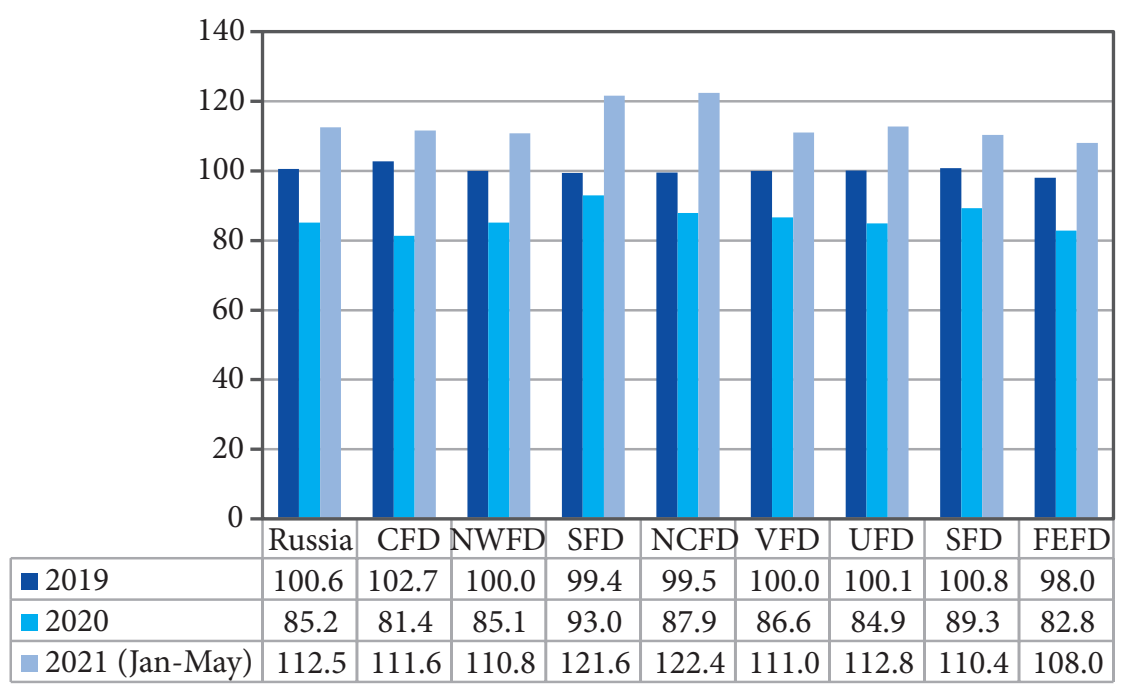

Figure 5. Dynamics of paid services to the population in the Russian Federation and federal districts

(in comparable prices in \% to the corresponding period of the previous year)

Source: authors' calculations were based on the official data from Rosstat.

Retrieved from: https://rosstat.gov.ru/folder/10705 (Accessed data: 10.07.2021) 
Moscow region. In Smolensk, Moscow, Kirov, and Nizhny Novgorod regions, the unemployment rate by May 2021 remained at the level of 2020, which means that the situation in the labour market remained tense, despite some improvements.

The North Caucasian Federal District, which generally follows the national trend, had the unemployment rate of $11.1 \%$ in 2019 (the maximum value for federal districts), and in 2020 it rose to $11.9 \%$. Of the seven constituent entities of the Russian Federation that are part of the North Caucasus Federal District, in six (excluding the Stavropol Territory), the unemployment rate has not dropped below 10\% since 2017, and in 2020 it was more than $14 \%$. The record high unemployment rates were observed in Ingushetia (30\%) and Chechnya (18.5\%). In Ingushetia, unemployment continued to rise in 2021, reaching 31.9\% by May. The structure of employment in the North Caucasus differs significantly from the rest of the regions. Outside the North Caucasus Federal District, a high level of unemployment (over 7\%), even after the situation improved in March-May 2021, persists in Karelia, the Nenets Autonomous Okrug, Adygea, Kalmykia, Kurgan region, the republics of Altai, Tyva and Khakassia, Omsk, Tomsk regions, Buryatia and the Trans-Baikal Territory, and in Tyva, the figure was $18.4 \%$, showing a worse situation even compared to 2020 .

Real income levels in the pre-crisis 2019 increased in all federal districts (from 0.4 to $2.8 \%$ ), which is close to the indicator for the Russian Federation as a whole (Fig. 7). During 2020, on average in Russia, real incomes of the population

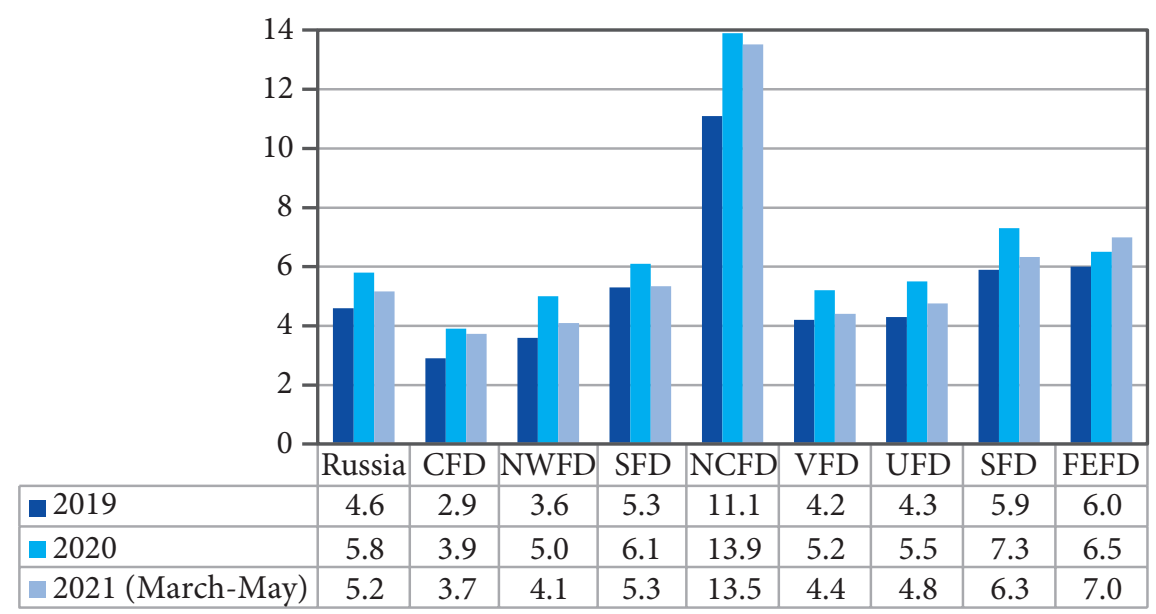

Figure 6. Dynamics of the unemployment rate on the national level and on the level of federal districts

(in\% of the labor force)

Source: the authors' calculations were based on the official data from Rosstat.

Retrieved from: https://rosstat.gov.ru/folder/10705 (Accessed data: 10.07.2021)

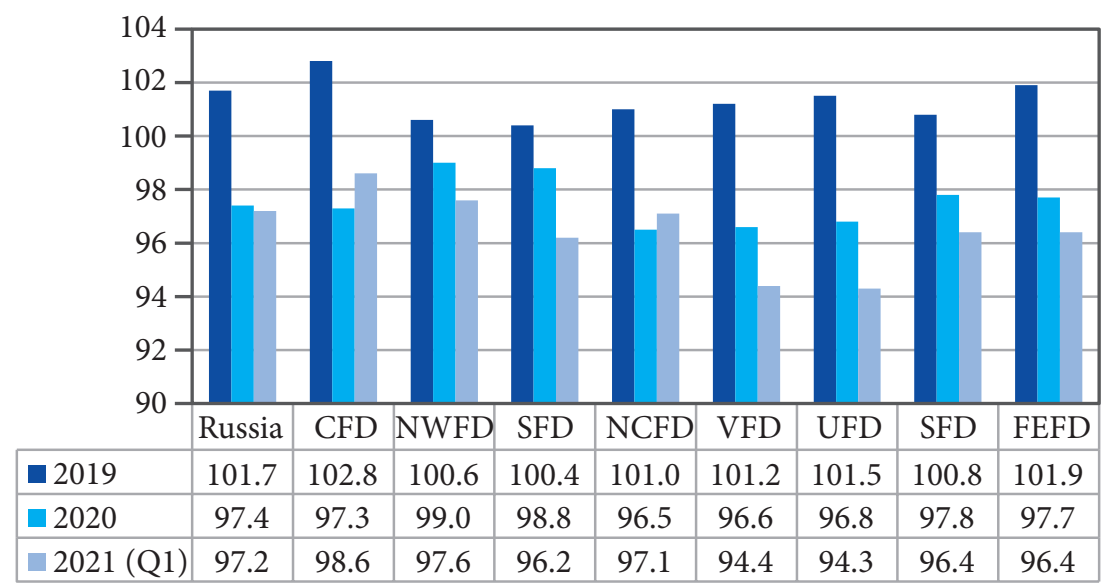

Figure 7. Dynamics of real money incomes of the population on the national level and on the level of federal districts (in\% to the corresponding period of the previous year)

Source: the authors' calculations were based on the official data from Rosstat.

Retrieved from: https://rosstat.gov.ru/folder/10705 (Accessed data: 10.07.2021) 
decreased by $2.6 \%$, at the end of the 1 st quarter of 2021, the downward trend in incomes continued, for most federal districts the same trend is characteristic, except the North-Western and North Caucasian federal districts, wherein the 1 st quarter of 2021, where the rate of decline in real incomes decreased, but even their incomes of the population decreased. Of the constituent entities of the Russian Federation, growth in real incomes of the population was recorded in 14 regions: Nenets Autonomous District, Leningrad Region, Kalmykia, Volgograd Region, Sevastopol, Mordovia, Chuvashia, the Yamal-Nenets Autonomous Okrug, the republics of Altai, Tyva and Khakassia, Magadan Region and the Chukotka Autonomous District. However, according to the results of the 1st quarter of 2021, there was only one constituent entity of the Russian Federation where real incomes were growing - Moscow. At the same time, the cost of the fixed set of goods and services calculated by Rosstat for interregional comparisons was growing. In 2019, the increase was $4.9 \%$; in $2020,6.1 \%$; and in the first quarter of $2021,5 \%$, which is significantly ahead of the inflation rate. Among federal districts, the maximum growth in this indicator in the first quarter of 2021 was recorded in the Ural Federal District - 6.5\%. In general, the negative dynamics of real incomes impedes the country's overcoming the economic consequences of the pandemic and is a significant factor that affects the growing social tension.

\section{Conclusions}

The country's economic system and regional economies adapted to the conditions of the first and second waves of the pandemic. The sharp decline in indicators characteristic of the first wave as well as on the national level gave way to stagnation, and after the end of the second wave, even to some revival. However, the economic changes in federal districts and regions did not proceed linearly; there was a tendency towards increased interregional. Not all territories that had previously shown relatively positive dynamics were able to adapt to the new conditions to the same extent some regions (such as the Krasnoyarsk Territory) faced significant problems, others - primarily large agglomerations - were able to quickly limit their negative dynamics, and in some cases show positive changes.

One of the striking features of the current crisis is the change in the role of the key factors of interregional competitiveness: previously one of the main dominants of success was the production of hydrocarbons, while in the current conditions this factor ceases to be decisive, as illustrates the example of the Ural Federal District and its regions. On the other hand, the factor of agglomeration development in combination with the metropolitan position remains highly significant and provides considerable advantages (for example, the Central and North-Western Federal Districts). Finally, as their own sources of income declined, both on the microlevel and on the regional level, the competition of territories for funds from the federal budget became a more decisive factor. In some cases, regions even managed to compensate for their economic losses and show high economic results - a striking example can be the North Caucasian Federal District and its constituent entities.

The third wave of the pandemic is unlikely to cause significant negative dynamics in most parts of the country, unless drastic restrictive measures are introduced by the state (so far such measures have been used only within Moscow). However, even without significant negative effects of the third wave, the country's socio-economic development is not stable, the recovery observed in the spring of 2021 is not sufficiently supported by long-term factors of economic growth, one of which should be an increase in domestic demand. The negative dynamics of real incomes of the population, observed in most territories of the Russian Federation, significantly slows down the country's recovery from the economic consequences of the pandemic and requires attention from the government.

\section{References}

Abramova, N.V. (2021). The impact Of the Pandemic On Small Business And Socio-Economic Situation In The Russian Regions. Vestnic altaiskoy akademii ekonomiki I prava = Bulletin of the Altai Academy of Economics and Law, 1(2), 112-117. (In Russ.). doi: 10.17513/vaael.1578

Adler, P., Florida, R., \& Hartt, M. (2020). Mega Regions and Pandemics. Tijdschrift voor Economische en Sociale Geografie, 111, 465-481. doi: 10.1111/tesg.12449 
Andrea, A., Faggian, A., \& Montresor, S. (2021). The geography of COVID-19 and the structure of local economies: The case of Italy. Journal of Regional Science, 61(2), 407-441. doi: 10.1111/ jors. 12510

Bailey, D., et al. (2020). Regions in a time of pandemic. Regional Studies, 54, 1163-1174. doi: $\underline{10.1080 / 00343404.2020 .1798611}$

Banai, R. (2020). Pandemic and the planning of resilient cities and regions. Cities, 106. doi: 10.1016/j.cities.2020.102929

Chisadza, C., Clance, M., \& Gupta, R. (2021). Government Effectiveness and the COVID-19 Pandemic. Sustainability, 13(6), 3042. doi: 10.3390/su13063042

Djankov, S., \& Panizza, U. (2020). COVID-19 in developing economies. London: CEPR Press, 385.

Ermakova, E.A. (2020). Financial policy of the region in the context of the new economic crisis and the coronavirus pandemic. Finance, 5, 19-24. (In Russ.).

Gordeev, S.S. (2020). Restrictions and transformations in the social space of the coronacrisis: assessments of regions in the COVID-19 pandemic. Socium $i$ vlast' $=$ Society and Power, 5(85), 32-50. (In Russ.). doi: 10.22394/1996-0522-2020-5-32-50

Gössling, S., Scott, D., \& Hall, C.M. (2020). Pandemics, tourism and global change: A rapid assessment of COVID-19. Journal of Sustainable Tourism, 29. doi: 10.1080/09669582.2020.1758708

Ivanov, D., \& Dolgui, A. (2020). Viability of intertwined supply networks: Extending the supply chain resilience angles towards survivability. A position paper motivated by COVID-19 outbreak. International Journal of Production Research, 58(10), 2904-2915. doi: 10.1080/00207543.2020.1750727

Kuchler, T., Russel, D., \& Stroebel, J. (2020). The geographic spread of COVID-19 correlates with structure of social networks as measured by Facebook. CESifo Working Paper, No. 8241, 12. Retrieved from: https://ssrn.com/abstract=3587255

Kuebart, A., \& Stabler M. (2020). Infectious diseases as socio-spatial processes: The COVID-19 outbreak in Germany. Tijdschrift voor Economische en Sociale Geografie. doi: 10.1111/tesg.12429

Kulova, M.R. (2020). The economy of the regions of the North Caucasus Federal District: inertia and variability in a pandemic. Ekonomika $i$ predprinimatelstvo $=$ Economics and Entrepreneurship, 11(124), 514-517. (In Russ.). doi: 10.34925/EIP.2020.124.11.095

Martinez-Azua, B.C., et al. (2021). Impact of the COVID-19 Pandemic on Agri-Food Companies in the Region of Extremadura (Spain). Agronomy, 11. doi: 10.3390/agronomy11050971

Matheson, J., Nathan, M., Pickard, H., \& Vanino, E. (2020). Why has coronavirus affected cities more than rural areas? Nations, Regions \& Cities. Retrieved from: https://www.coronavirusandtheeconomy.com/question/why-hascoronavirus-affected-cities-more-rural-areas

Milchakov, M.V. (2021). Implementation of regional development priorities in a pandemic. Finansovii zhurnal = Financial Journal, 2, 93-113. (In Russ.). doi: 10.31107/2075-1990-2021-2-93-113

Morita, H., Nakamura, S., \& Hayashi, Y. (2020). Changes of urban activities and behaviors due to COVID-19 in Japan, 8. Retrieved from: https://ssrn.com/abstract=3594054

Pobedin, A.A. (2014). Cyclicity as a factor in the uneven development of the economic space of the region. Economics and Politics, 2 (3), 157-168. (In Russ.).

Rodionov, D.G., et al. (2021). A Transformation of the Approach to Evaluating a Region's Investment Attractiveness as a Consequence of the COVID-19 Pandemic, Economies, 59. doi: 10.3390/ economies9020059

Sleptsov, A.N., \& Potravnaya, E.V. (2020). Impact of the coronavirus pandemic on the life of arctic regions in population estimates. Sotsiologicheskie issledovaniya, 7, 144-147. doi: $10.31857 /$ $\underline{\text { S013216250009621-6 }}$

Stepanova D.I. (2020). Causes of the budgetary crisis of the regions of Russia. Education, Science, Scientific Personnel, 3, 164-166. (In Russ.) doi: 10.24411/2073-3305-2020-10167

Tarasova, M.V., \& Tarasov S.A. (2020). Systemic problems of the regional labor market and its prospects in the post-pandemic period (on the example of the Rostov region). Politics, Economics and Innovation, 4(33). (In Russ.). Retrieved from: http://pei-journal.ru/index.php/PEII/article/view/928/pdf

Tsukhlo, S.V. (2021) Russian industry in April 2021: signs of the end of the crisis. Economic Development of Russia, 5, 21-23. (In Russ.). 
Turgel, I., Pobedin, A., \& Bozhko, L. (2020). Spatial socio-economic heterogeneity of rural areas in the Russian Federation. E3S Web of Conferences, doi: 10.1051/e3sconf/202022206022

Vladislavleva, T.B., \& Kerov, V.A. (2020). Public management of regional development in the context of the COVID-19 pandemic. Public Administration. Electronic Bulletin, 83, 22-46. (In Russ.)

Zotikov, N.Z. (2020). Socio-economic situation of regions in the context of a pandemic (on the example of the regions of the Volga Federal District). Oeconomia et Jus, 3, 9 (In Russ.). doi: 10.47026/2499-9636-2020-3-9-26

Zubarevich, N. V. (2020). Pandemic and regions: results of January-August 2020. Economic Development of Russia, 11, 91-95. (In Russ.).

Zubarevich, N.V. (2021). The impact of the pandemic on socio-economic development and regional budgets. Theoretical Economics Issues, 1, 48-60. (In Russ.). doi: 10.24411/2587-7666-2021-10104

\section{Information about the authors}

Alexander A. Pobedin - Ph.D. Economics, Associate Professor, Head of the Department of Economics and Management, The Russian Presidential Academy of National Economy and Public Administration (The Presidential Academy, RANEPA) (66 8 Marta St., Yekaterinburg, 620144, Russia); e-mail: pobedin-aa@ranepa.ru

Natalya R. Balynskaya - Doctor of Political Sciences, Professor, Director of the Institute of Economics and Management, Head of the Department of State Municipal Administration and Personnel Management, Nosov Magnitogorsk State Technical University (38 Lenina av., Magnitogorsk, 455000, Russia); e-mail: balynskaya@list.ru

Dina Williams - PhD, Associated Lecturer, Open University (Walton Hall, Kents Hill, Milton Keynes MK7 6AA, United Kingdom); e-mail: dina.williams10@gmail.com

ARTICLE INFO: received June 24, 2021; accepted August 27, 2021

\section{Информация об авторах}

Победин Александр Александрович - кандидат экономических наук, доцент, заведующий кафедрой экономики и управления, Уральский институт управления - филиал Российской академии народного хозяйства и государственной службы при Президенте РФ (620144, Россия, Екатеринбург, ул. 8 Марта, 66); e-mail: pobedin-aa@ranepa.ru

Балынская Наталья Ринатовна - доктор политических наук, профессор, директор института экономики и управления, заведующая кафедрой государственного муниципального управления и управления персоналом, Магнитогорский государственный технический университет им. Г.И. Носова (455000, Россия, Магнитогорск, пр. Ленина, 38); e-mail: balynskaya@list.ru

Уильямс Дина - PhD, преподаватель, Открытый университет (MK7 6AA, Великобритания, Милтон Кейнс, Уолтон Холл, Кентс Хилл); e-mail: dina.williams10@gmail.com

ИНФОРМАЦИЯ О СТАТЬЕ: дата поступления 24 июня 2021 г.; дата принятия к печати 27 августа 2021 г. 